Note

\title{
Evaluation of the Antiviral Activity of Chlorine Dioxide and Sodium Hypochlorite against Feline Calicivirus, Human Influenza Virus, Measles Virus, Canine Distemper Virus, Human Herpesvirus, Human Adenovirus, Canine Adenovirus and Canine Parvovirus
}

\author{
TAKESHI SANEKATA ${ }^{1 *}$, TOSHIAKI FUKUDA ${ }^{2}$, TAKANORI MIURA ${ }^{2}$, \\ HIROFUMI MORINO ${ }^{2}$, CHEOLSUNG LEE ${ }^{2}$, KEN MAEDA ${ }^{3}$, KAZUKO ARAKI ${ }^{4}$, \\ TORU OTAKE ${ }^{5}$, TAKUYA KAWAHATA ${ }^{5}$, AND TAKASHI SHIBATA ${ }^{2}$
}

\begin{abstract}
Laboratory of Veterinary Infectious Disease, Faculty of Agriculture, Tottori University, 4-101 Koyama, Tottori 680-8553, Japan, '2Taiko Pharmaceutical Co., Ltd., 3-34-14 Uchihonmachi, Suita 564-0032, Japan,

${ }^{3}$ Department of Veterinary Medicine, Faculty of Agriculture, Yamaguchi University, 1677-1 Yoshida,

Yamaguchi 753-8515, Japan, ${ }^{4}$ Infectious Disease Surveillance Center, National Institute of Infectious

Disease, 1-23-1 Toyama, Shinjuku, Tokyo 162-8640, Japan, and ${ }^{5}$ Division of virology,

Department of infectious diseases, Osaka Prefectural Institute of Public Health,
\end{abstract}

1-3-69 Nakamichi, Higashinari-ku, Osaka 573-0025, Japan

Received 15 June, 2009/Accepted 29 December, 2009

\begin{abstract}
We evaluated the antiviral activity of a chlorine dioxide gas solution (CD) and sodium hypochlorite (SH) against feline calicivirus, human influenza virus, measles virus, canine distemper virus, human herpesvirus, human adenovirus, canine adenovirus and canine parvovirus. $C D$ at concentrations ranging from 1 to $100 \mathrm{ppm}$ produced potent antiviral activity, inactivating $\geq 99.9 \%$ of the viruses with a $15 \mathrm{sec}$ treatment for sensitization. The antiviral activity of CD was approximately10 times higher than that of SH.
\end{abstract}

Key words : Virus inactivation/Antiviral activity/Chlorine dioxide/Sodium hypochlorite.

In recent years, the high incidence of norovirus infections in households, schools and nursing institutions for the elderly (Tsang et al., 2008) and the prevalence of measles in high schools (Sasaki et al., 2007) have become an increasing problem in Japan. In particular, norovirus can be transmitted orally, and it takes only a small amount of virus to cause acute gastroenteritis (Lindesmith et al., 2003) and sometimes even death among the elderly.

It is very important to develop safe and effective antiviral disinfectants. We evaluated the antiviral activity of a chlorine dioxide disinfectant, "chlorine dioxide gas solution" (long-life type, hereinafter referred

*Corresponding author. Tel : +81-857-31-5679, Tax: +81857-31-5679. to as $\mathrm{CD}$ ), and sodium hypochlorite ( $\mathrm{SH}$ ) against feline calicivirus (FCV, a surrogate for norovirus), human influenza virus (IFV), measles virus, canine distemper virus (CDV), human herpesvirus (HHV), human adenovirus ( $\mathrm{HAd}$ ), canine adenovirus (CAd) and canine parvovirus (CPV).

Effective antiviral disinfectants are needed to prevent infections of these highly contagious viruses. $\mathrm{SH}$, a disinfectant commonly used against norovirus (Bruce et al., 1985), has the drawbacks of generating trihalomethane (Patterson et al., 1995; Wistrom et al., 1996), possessing an irritating odor, and undergoing a decrease in concentration during storage.

CD does not generate trihalomethane (Don, 1998), and the disinfecting effect of CD is less affected by $\mathrm{pH}$ compared to chlorine, has a less irritating odor 
and has a superior concentration stability during storage.

The viruses, strains and cells used in the present study were as follows: FCV: F4, CRFK; IFV: New Caledonia/20/99, Chick embryo; Measles virus: Edomonston, Vero/hSLAM; CDV: Onderstepoort, Vero; HHV-1: KOS, CRFK; HAd-2: wild, A549; CAd-2: Vaccine, BK; CPV: Y-I, CRFK.

The disinfectants studied were CD (Cleverin $^{\top \mathrm{M}}$, Taiko Pharmaceutical Co., Ltd., Osaka, Japan) and $\mathrm{SH}$ (Wako Pure Chemical Industries Ltd., Osaka, Japan).

All viruses except for IFV were prepared as follows. Cells cultured in Eagle's minimum essential medium (MEM) containing 10\% fetal bovine serum (FBS), which was used as a growth medium, were inoculated with each virus and incubated at $37^{\circ} \mathrm{C}$ until a cytopathic effect (CPE) was observed. The virus culture fluid was subjected to three freeze-thaw cycles and then purified and concentrated. Regarding IFV, after the virus culture fluid was inoculated into the chorioallantoic cavity of 10-day-old embryonated chicken eggs and incubated for 3 days at $34^{\circ} \mathrm{C}$, the chorioallantoic fluid was harvested.

Virus culture fluids were subjected to low-speed centrifuge for cell removal, and then concentrated and purified through a 20\% sucrose cushion. To the resultant sediment, $2 \mathrm{~mL}$ of distilled water was added, and the virus culture was ultimately concentrated to 500 times its original concentration. Virus suspensions were sterile-filtered through a $0.45 \mu \mathrm{m}$-pore size membrane filter, and the filtrate was stored frozen at $-80^{\circ} \mathrm{C}$ until ready for use.

Drug treatment of viruses was performed as follows. Each drug was diluted with sterilized distilled water for concentration adjustment. To $240 \mu \mathrm{L}$ of each drug at each concentration (1,250 ppm, 125 ppm, $12.5 \mathrm{ppm}, 1.25 \mathrm{ppm}, 0.125 \mathrm{ppm}$ and 0.0125 ppm), $60 \mu \mathrm{L}$ of virus filtrate was added and stirred for $15,30,60,120$ and 180 seconds for sensitization. Then, from each reaction solution, $50 \mu \mathrm{L}$ of virus was harvested, and $450 \mu \mathrm{L}$ of $5 \mathrm{mM}$ sodium thiosulfate was added to neutralize the disinfectant. As virus controls, viruses treated with distilled water instead of diluted drugs were used. Tenfold serial dilutions of neutralized viruses were prepared with MEM to determine the infectivity titer (50\% tissue culture infective dose $\left.\left[\mathrm{TClD}_{50}\right]\right)$. The concentration of $\mathrm{SH}$ and $\mathrm{CD}$ were estimated by the DPK kit (type CN-66F, HACH Com. lowa, USA) and spectrophotometric method (Sjestrem and Disa, 1976), respectively.

All examinations were carried out in biosafety level 2 laboratories.

Infectivity titer determination for FCV, IFV, measles virus, CDV, HHV-1, HAd-2, CAd-2 and CPV was carried out as follows. Host cells for each virus plated in a 96-well microplate $(100 \mu \mathrm{L} /$ well) were incubated for 3 days at $37^{\circ} \mathrm{C}$ in a $5 \%$ carbon dioxide incubator. The cells were then washed with MEM, and inoculated with the diluted virus (4 wells for each dilution, $50 \mu \mathrm{L} /$ well). After 60 min of viral adsorption onto the cells at $37^{\circ} \mathrm{C}$ in a $5 \%$ carbon dioxide incubator, the cells were washed with MEM twice. After incubation for 5 days at $37^{\circ} \mathrm{C}$ with an addition of $100 \mu \mathrm{L}$ of MEM in a $5 \%$ carbon dioxide incubator, $\mathrm{TCID}_{50} / 50 \mu \mathrm{L}$ was calculated by microscopic examination of CPE. Antiviral activity (\%) was calculated as follows: antiviral activity $(\%)=\{1-$ (infectivity of each treated virus/virus control) $\} \times 100$

Table 1 shows the reduction of infectivity of various viruses by the $\mathrm{CD}$ and $\mathrm{SH}$ treatment.

Against FCV, CD exhibited no measurable effect with $1.0 \mathrm{ppm}$ treatment for $180 \mathrm{sec}$, but produced antiviral activity against $\geq 99.99 \%$ of the virus with $10 \mathrm{ppm}$ treatment for $15 \mathrm{sec}$. SH had no antiviral effect at $10 \mathrm{ppm}$, but showed antiviral activity against $\geq 99.99 \%$ of the virus at $100 \mathrm{ppm}$ treated for $15 \mathrm{sec}$.

Against IFV, CD produced antiviral activity against $\geq 99.99 \%$ of the virus with $1.0 \mathrm{ppm}$ treatment for 15 sec. On the other hand, antiviral activity against $99.99 \%$ of the virus was obtained for $\mathrm{SH}$ with 100 ppm treatment for $15 \mathrm{sec}$.

Against Measles virus, antiviral activity against $\geq$ $99.99 \%$ of the virus was observed at $10 \mathrm{ppm}$ for 30 $\mathrm{sec}$ or at $100 \mathrm{ppm}$ for $15 \mathrm{sec}$ with CD treatment, and at $100 \mathrm{ppm}$ for $30 \mathrm{sec}$ or at $1000 \mathrm{ppm}$ for $15 \mathrm{sec}$ with $\mathrm{SH}$ treatment.

Against CDV, antiviral activity for $99.99 \%$ of the virus was demonstrated at $10 \mathrm{ppm}$ for $15 \mathrm{sec}$ for CD treatment and at $100 \mathrm{ppm}$ for $30 \mathrm{sec}$ with $\mathrm{SH}$ treatment.

Against HHV-1: CD produced antiviral activity against $99.9 \%$ of the virus with $10 \mathrm{ppm}$ treatment for $15 \mathrm{sec}$, while SH treatment at $10 \mathrm{ppm}$ for $180 \mathrm{sec}$ resulted in antiviral activity against $99 \%$ of the virus.

Against HAd-2 and CAd-2, antiviral activity of CD was observed against $99.99 \%$ of the virus with 10 ppm treatment for $15 \mathrm{sec}$, whereas $\mathrm{SH}$ required a concentration ten times higher than that of $C D$ to produce an equivalent effect.

However CPV was resistant to both disinfectants; antiviral activity against $\geq 99.99 \%$ of this virus was obtained at $10 \mathrm{ppm}$ for $180 \mathrm{sec}$ or at $100 \mathrm{ppm}$ for 15 sec with $\mathrm{CD}$ treatment in comparison to $\mathrm{SH}$ treatment at $100 \mathrm{ppm}$ for $120 \mathrm{sec}$.

The present study examined the antiviral activity of $\mathrm{CD}$ and $\mathrm{SH}$ against RNA viruses such as FCV, IFV, measles virus and CDV, as well as DNA viruses such 
TABLE 1. Reduction of infectivity of various viruses by the treatment with CD and SH

\begin{tabular}{|c|c|c|c|c|c|c|c|c|}
\hline \multirow{2}{*}{ Virus } & \multirow{2}{*}{ Disinfectants } & \multirow{2}{*}{$\begin{array}{l}\text { Concentration } \\
\text { ppm }\end{array}$} & \multirow{2}{*}{$\begin{array}{l}\text { Virus } \\
\text { control }\end{array}$} & \multicolumn{5}{|c|}{ Treatment (seconds) } \\
\hline & & & & 15 & 30 & 60 & 120 & 180 \\
\hline \multirow[t]{8}{*}{ FCV } & Chlorine dioxide & 0.1 & 6.75 & 6.75 & 6.75 & 6.75 & 6.75 & 6.75 \\
\hline & & 1.0 & 6.75 & 6.75 & 6.75 & 6.75 & 6.75 & 6.5 \\
\hline & & 10 & 6.75 & 1.5 & 1.0 & 1.0 & 0.75 & 0.75 \\
\hline & & 100 & 6.75 & $<0.5$ & $<0.5$ & $<0.5$ & $<0.5$ & $<0.5$ \\
\hline & Sodium hypochlorite & 1 & 6.75 & 6.75 & 6.75 & 6.5 & 6.5 & 6.5 \\
\hline & & 10 & 6.75 & 6.5 & 6.5 & 6.5 & 6.25 & 6.25 \\
\hline & & 100 & 6.75 & 0.75 & 0.75 & 0.75 & 0.75 & 0.75 \\
\hline & & 1000 & 6.75 & $<0.5$ & $<0.5$ & $<0.5$ & $<0.5$ & $<0.5$ \\
\hline \multirow[t]{7}{*}{ IFV } & Chlorine dioxide & 0.1 & 6.5 & 4.75 & 4.5 & 4.0 & 3.75 & 3.75 \\
\hline & & 1.0 & 6.5 & 2.25 & 2.25 & 2.0 & 1.5 & 1.5 \\
\hline & & 10 & 6.5 & $<0.5$ & $<0.5$ & $<0.5$ & $<0.5$ & $<0.5$ \\
\hline & & 100 & 6.5 & $<0.5$ & $<0.5$ & $<0.5$ & $<0.5$ & $<0.5$ \\
\hline & Sodium hypochlorite & 1 & 6.5 & 5.5 & 5.5 & 5.5 & 5.5 & 4.75 \\
\hline & & 10 & 6.5 & 3.5 & 3.5 & 3.5 & 2.75 & 2.75 \\
\hline & & 100 & 6.5 & $<0.5$ & $<0.5$ & $<0.5$ & $<0.5$ & $<0.5$ \\
\hline \multirow{7}{*}{$\begin{array}{l}\text { Measles } \\
\text { virus }\end{array}$} & Chlorine dioxide & 1.0 & 5.5 & 4.5 & 4.25 & 4.0 & 4.0 & 3.75 \\
\hline & & 10 & 5.5 & 2.0 & $<0.5$ & $<0.5$ & $<0.5$ & $<0.5$ \\
\hline & & 100 & 5.5 & $<0.5$ & $<0.5$ & $<0.5$ & $<0.5$ & $<0.5$ \\
\hline & Sodium hypochlorite & 1.0 & 5.5 & 5.0 & 4.75 & 4.75 & 4.75 & 4.75 \\
\hline & & 10 & 5.5 & 4.5 & 4.5 & 3.75 & 3.75 & 3.75 \\
\hline & & 100 & 5.5 & 4.75 & $<0.5$ & $<0.5$ & $<0.5$ & $<0.5$ \\
\hline & & 1000 & 5.5 & $<0.5$ & $<0.5$ & $<0.5$ & $<0.5$ & $<0.5$ \\
\hline \multirow[t]{8}{*}{ CDV } & Chlorine dioxide & 0.1 & 5.5 & 5.5 & 5.5 & 5.5 & 5.5 & 5.5 \\
\hline & & 1.0 & 5.5 & 2.75 & 1.75 & 1.75 & 1.75 & 1.75 \\
\hline & & 10 & 5.5 & $<0.5$ & $<0.5$ & $<0.5$ & $<0.5$ & $<0.5$ \\
\hline & & 100 & 5.5 & $<0.5$ & $<0.5$ & $<0.5$ & $<0.5$ & $<0.5$ \\
\hline & Sodium hypochlorite & 1.0 & 5.5 & 5.5 & 5.5 & 5.5 & 5.5 & 5.5 \\
\hline & & 10 & 5.5 & 5.5 & 5.5 & 5.5 & 5.5 & 5.5 \\
\hline & & 100 & 5.5 & 2.5 & 1.5 & $<0.5$ & $<0.5$ & $<0.5$ \\
\hline & & 1000 & 5.5 & $<0.5$ & $<0.5$ & $<0.5$ & $<0.5$ & $<0.5$ \\
\hline \multirow[t]{6}{*}{$\mathrm{HHV}-1$} & Chlorine dioxide & 0.1 & 5.0 & 4.25 & 4.0 & 3.75 & 3.75 & 3.75 \\
\hline & & 1.0 & 5.0 & 3.75 & 3.50 & 3.0 & 3.0 & 3.0 \\
\hline & & 10 & 5.0 & 1.5 & 1.25 & 1.25 & 1.25 & 1.25 \\
\hline & Sodium hypochlorite & 0.1 & 5.0 & 4.5 & 4.25 & 4.25 & 4.25 & 4.25 \\
\hline & & 1.0 & 5.0 & 4.75 & 4.5 & 4.25 & 4.25 & 4.25 \\
\hline & & 10 & 5.0 & 3.75 & 3.75 & 3.25 & 3.0 & 3.0 \\
\hline \multirow[t]{8}{*}{ HAd-2 } & Chlorine dioxide & 0.1 & 6.5 & 6.0 & 6.0 & 6.0 & 6.0 & 6.0 \\
\hline & & 1.0 & 6.5 & 5.0 & 5.0 & 5.0 & 5.0 & 5.0 \\
\hline & & 10 & 6.5 & 1.5 & 1.5 & 1.5 & 1.5 & 1.5 \\
\hline & & 100 & 6.5 & $<0.5$ & $<0.5$ & $<0.5$ & $<0.5$ & $<0.5$ \\
\hline & Sodium hypochlorite & 1.0 & 6.5 & 6.0 & 6.0 & 6.0 & 6.0 & 6.0 \\
\hline & & 10 & 6.5 & 5.5 & 5.5 & 5.5 & 5.5 & 5.5 \\
\hline & & 100 & 6.5 & 1.5 & 1.5 & 1.5 & 1.5 & 1.5 \\
\hline & & 1000 & 6.5 & $<0.5$ & $<0.5$ & $<0.5$ & $<0.5$ & $<0.5$ \\
\hline \multirow[t]{8}{*}{ CAd-2 } & Chlorine dioxide & 0.1 & 6.5 & 6.0 & 6.0 & 6.0 & 6.0 & 6.0 \\
\hline & & 1.0 & 6.5 & 6.0 & 6.0 & 6.0 & 6.0 & 6.0 \\
\hline & & 10 & 6.5 & $<0.5$ & $<0.5$ & $<0.5$ & $<0.5$ & $<0.5$ \\
\hline & & 100 & 6.5 & $<0.5$ & $<0.5$ & $<0.5$ & $<0.5$ & $<0.5$ \\
\hline & Sodium hypochlorite & 1.0 & 6.5 & 6.0 & 6.0 & 6.0 & 6.0 & 6.0 \\
\hline & & 10 & 6.5 & 6.0 & 6.0 & 6.0 & 6.0 & 6.0 \\
\hline & & 100 & 6.5 & $<0.5$ & $<0.5$ & $<0.5$ & $<0.5$ & $<0.5$ \\
\hline & & 1000 & 6.5 & $<0.5$ & $<0.5$ & $<0.5$ & $<0.5$ & $<0.5$ \\
\hline \multirow[t]{8}{*}{ CPV } & Chlorine dioxide & 0.1 & 4.5 & 4.25 & 4.5 & 4.5 & 4.5 & 4.5 \\
\hline & & 1.0 & 4.5 & 4.5 & 4.5 & 4.5 & 4.5 & 4.5 \\
\hline & & 10 & 4.5 & 3.25 & 2.25 & 2.0 & 1.0 & $<0.5$ \\
\hline & & 100 & 4.5 & $<0.5$ & $<0.5$ & $<0.5$ & $<0.5$ & $<0.5$ \\
\hline & Sodium hypochlorite & 0.1 & 4.5 & 4.5 & 4.5 & 4.25 & 4.25 & 3.75 \\
\hline & & 1.0 & 4.5 & 4.0 & 4.0 & 4.0 & 4.5 & 4.5 \\
\hline & & 10 & 4.5 & 2.75 & 2.75 & 2.25 & 2.0 & 2.0 \\
\hline & & 100 & 4.5 & 2.75 & 2.5 & 1.0 & $<0.5$ & $<0.5$ \\
\hline
\end{tabular}


as HHV, HAd-2, CAd-2 and CPV.

Antiviral activity against norovirus was determined using FCV. CD at $10 \mathrm{ppm}$ for $15 \mathrm{sec}$ inactivated $\geq$ 99.99\% of the virus, whereas $\mathrm{SH}$ required 10 times higher concentrations than CD to produce an equivalent effect. This observation indicates that CD has the potential to be used as a disinfectant against norovirus.

In addition, against other viruses, CD was equivalent to $\mathrm{SH}$ in terms of its antiviral activity at $1 / 10$ concentrations.

Treatment with these disinfectants for sensitization at lower concentrations for up to $180 \mathrm{sec}$ was performed; longer durations of treatment were not associated with any increase in antiviral activity. Meanwhile, sensitization at higher concentrations resulted in a more potent antiviral effect as indicated by the infectivity titer, showing that the disinfectant concentration is an important factor for virus inactivation.

$C D$ exhibited antiviral activity in the concentration range from 0.1 to $10 \mathrm{ppm}$, which was $1 / 10$ that of $\mathrm{SH}$. Having antiviral activity at lower concentrations than $\mathrm{SH}, \mathrm{CD}$ is expected to be useful as a virus disinfectant.

$C D$, which has demonstrated antiviral activity and is known to be less likely to generate trihalomethane (Wistrom et al., 1996), is a potent alternative disinfectant to SH (Junli et al., 1997). The CD used in the present study has the advantage of maintaining concentration levels of chlorine dioxide over an extended period. Since chlorine dioxide is also available in gaseous form (Ogata and Shibata., 2008), it can be directly sprayed in wards and laboratories in hospitals, meal preparation rooms in school lunch centers and other places, which may contribute to better prevention of hospital-acquired infections and food poisoning.

In the present study, the antiviral activity of disinfectants was determined under contamination-free conditions. Since it has been reported that contamination of disinfectants with proteins or other foreign materials results in decreased antiviral activity, it will be necessary to assess the antiviral activity using purified virus solutions containing FBS or other appropriate contaminants.

In Europe and the US, the use of chlorine dioxide to disinfect tap water has been implemented (Aleta and Berg, 1986; Lykins et al., 1990). The results of the present study provide an additional support for the use of CD as an antiviral agent; it also has several advantages over $\mathrm{SH}$. Therefore, $\mathrm{CD}$ may be used more frequently in the future.

While detailed reports on the mechanisms of SH's antiviral activity are not available to our knowledge,
CD has been reported to produce its antiviral activity by acting on virus nucleic acids and on virus proteins (Li et al., 2002), and by oxidizing amino acids tryptophan and tyrosine (Ogata and Shibata, 2008). In the present study, CD's antiviral activity was observed against both RNA and DNA viruses regardless of the presence/absence of the envelope, which is interesting to clarify the mechanisms of action. The higher antiviral activity of $\mathrm{CD}$ compared to that of $\mathrm{SH}$ may be attributable to differences in the mechanisms of action.

To confirm the feasibility of CD use in clinical and environmental settings, assessment of the viral growth inhibitory effect of CD under conditions of protein contamination and of the use of $C D$ in aerosol form is necessary.

\section{ACKNOWLEDGEMENTS}

We thank Dr. Yukinobu Tohya, Dr. Yoshinobu Okuno, and Dr. Yusuke Yanagi for the preparation of viruses and cells, Feline calicivirus F4 strain, New Caledonia strain influenza A virus and Vero cells.

\section{REFERENCES}

Aleta, E., M., and Berg, J. D. (1986) A review of chlorine dioxide in drinking water treatment J. Am. Water Works Assoc., 78, 62-72.

Bruce, H., Keswick, B. H., Satterwhite, T. K., Johnson, P. C., Dupont, H. L., Secor, S. L., Bitsura, J. A., Gary, G. W., and Hoff. J. C. (1985) Inactivation of Norwalk virus in Drinking Water by chlorine. Appl. Environ. Microbiol., 50, 261-264.

Don, G. (1998) The chlorine dioxide handbook. Am. Water Works Assoc. 3-4.

Thurston-Enriquez, J. A., Haas, C. N., Jacangelo, J., and Gerba, C.P. (2003) Chlorine inactivation of adenovirus type 40 and feline calicivirus. Appl. Environ. Microbiol., 69, 3979-3985.

Junli, H., Li, W., Nenqi, R., Li, L. X., Fun, S. R., and Guanle, Y. (1997) Disinfection effect of chorine dioxide on viruses, algae and animal planktons in water. Wat. Res., 31, 455-460.

Li, J. W., Xin, Z. T., Wang, X. W., Zheng, J. L. and Chao, F. H. (2002) Mechanisms of inactivation of hepatitis A virus by chlorine. Appl. Environ. Microbiol., 68, 4951-4955.

Lindesmith, L., Moe C., Marionneau, S., Ruvoen, N., Jiang, X., Lindbland, L., Stewart, P., LePendu, J., and Baric, R. (2003) Human susceptibility and resistance to Norwalk virus infection. Nature Medicine, 9, 548-553.

Lykins, B. W., Goodrich, J. A., and Hoff, J. C. (1986) Concern with using chlorine-dioxide disinfection in the USA. J. water., 39, 376-386.

Ogata, N. and Shibata, T. (2008) Protective effect of lowconcentration chlorine dioxide gas against influenza $A$ virus infection. J. Gen. Virol., 89, 60-67.

Patterson, K. S., Lykins Jr. B. W., and Richardson, S. D. (1995) Mutagenicity of drinking water following disinfection. J. Aqua. 44, 1-9.

Sasaki, A., Suzuki, H., Sakai, T., Sato, M., Sakai, T., Sato, 
M., Shobugawa, Y., and Sato, R. (2007) Measles outbreaks in high schools closely associated with sporting events in Niigata, Japan. J. infection, 55, 179-183.

Sjestrem, L. and Tormund, D. (1978) Determination of inorganic chlorine compounds and total chlorine in spent bleaching liquors, Part 2. Spectrophotmetetric methods for chlorine dioxide and chlorine. Sven Papperstidning, 81, 114-120.
Tsang, O. T. Y., Wong, A. T. Y., Chow, C. B., Yung, R. W. H., Lim, W. W. L., and Liu, S. H. (2008) Clinical characteristics of nosocomical norovirus outbreaks in Hong Kong. J. Hospital infect. 69, 135-140.

Wistrom, A. O., Chou, T., Chang, D. P. Y., and Schroeder, E.D. (1996) A method for Measuring haloform formation during wastewater chlorination. War. Res., 30, 31463151. 